\title{
Modeling Neurofibromatosis Type 1 Tumors in the Mouse for Therapeutic Intervention
}

\author{
L.F. PARADA, C.-H. KwON, AND Y. ZHU \\ Center for Developmental Biology, University of Texas Southwestern Medical Center,
} Dallas, Texas 75390-9133

\begin{abstract}
Von Recklinghausen's neurofibromatosis is a dominantly inherited cancer syndrome. Its gene encodes neurofibromin, a protein with ras GTPase-activating function (rasGAP) and, therefore, all NF1-associated pathology is thought to originate from selective deregulation of the ras pathway. We have constructed a variety of mouse models for NF1 that permit recapitulation of the most common tumors seen in patients. In addition, these mouse models offer insights into tumor origin and into paracrine interactions. Given the molecular and pathological fidelity of the mouse tumors to the human counterparts, it is hoped that these mouse strains will serve as effective tools for therapeutic discovery.
\end{abstract}

Von Recklinghausen's neurofibromatosis type 1 (NF1) is a common genetic disease that affects 1 in 3000 individuals worldwide. Individuals born with a germ-line mutation in the NF1 gene are susceptible to many pathological conditions, including intellectual deficits, abnormal bone development, and hypertension (Cichowski and Jacks 2001; Zhu and Parada 2001). However, these abnormalities are of variable penetrance. In contrast, tumor development is a frequent hallmark of NF1. Virtually all NF1 patients develop benign tumors of the peripheral nerves called neurofibromas. Individuals with plexiform neurofibromas, involving large segments of peripheral nerve, are at high risk to develop malignant peripheral nerve sheath tumors (MPNSTs), an incurable form of cancer. NF1 patients also have increased susceptibility to develop astrocytomas. Although estimates vary, as many as $25 \%$ of NF1 patients have optic nerve astrocytomas (pilocytic astrocytomas), and the incidence of glioblastoma among NF1 patients is greater than fivefold that of the population at large (Zhu et al. 2005). Thus, NF1 is a classic tumor suppressor locus (Zhu and Parada 2002).

The gene encoding NF1 was cloned independently by two groups in 1990 (Ballester et al. 1990; Xu et al. 1990b). The sequence revealed a large protein of $2900+$ amino acids that contains a domain highly homologous to yeast Ira sequences which have rasGTPase-enhancing activity (Viskochil 1999). Subsequent studies from many groups have demonstrated that the NF1 protein, neurofibromin, is indeed a functional rasGAP protein (Xu et al. 1990a; Bollag and McCormick 1991). A close NF1 homolog in Drosophila has been reported to have predominant activity in cAMP-dependent pathway activation, although these results remain controversial (Guo et al. 1997; The et al. 1997). In summary, the majority of current information supports the idea that NF1 pathology can be attributed to deregulation of the ras pathway in a variety of cellular contexts (Klesse and Parada 1998; Zhu et al. 2002; Le et al. 2004).

In the course of the past decade, we have sought to model NF1 disease in the mouse. Initial studies employed classic gene knockout technology, and resultant NF1 null mice were developed. Several important insights were obtained using these mice, despite the fact that they perish embryonically at about E13.0 of development (Brannan et al. 1994; Jacks et al. 1994; Zhu et al. 2001).

The observation that NF1 heterozygous mice did not develop the frequent tumor types seen in patients was initially confounding. Aged NF1 heterozygotes did show susceptibility to pheochromocytomas, a rare tumor in NF1 but nonetheless more frequent than non-NF1-associated tumors (Jacks et al. 1994). Whereas in NF1 patients MPNSTs only arise in the context of neurofibromas, studies of these malignant tumors have demonstrated the existence of additional mutations, particularly in the p53 and Arf tumor suppressors. To test whether addition of such mutations would enhance tumor susceptibility, we, and T. Jacks independently, generated mice that were doubly heterozygous for both NF1 and p53 in the germ line. These mutations were carried in cis, since the tumor suppressors are linked both in mouse and in humans. The outcome was one of fully penetrant development of MPNSTs (Cichowski et al. 1999; Vogel et al. 1999). Histopathological and molecular analysis demonstrated remarkable similarity to human MPNST samples from NF1 patients. These data provide a proof of principle that NF1 could be modeled in mice. The appearance of MPNSTs directly in these mice was always associated with loss of the functional copies of both the NF1 and p53 genes.

We reasoned that one possibility to explain the absence of neurofibromas in NF1 heterozygous mice was essentially a reduced window of opportunity. In humans, loss of heterozygosity (LOH) of the NF1 locus presumably occurs stochastically, in the tumor target population during embryonic development. In mice, the considerably reduced time of gestation and relatively smaller number of neural-crest-derived precursors could simply undermine the likelihood of an effective LOH event in the appropriate cell to induce tumor formation. To develop more precise mouse models for NF1-associated tumorigenicity, we turned to Cre/loxP technology that permits more se- 
lective spatial and temporal ablation of NF1 function. LoxP sites were introduced into the NF1 locus to flank exons 32-34, thereby mimicking the original null mutation. The flox allele of NF1 is equivalent to the wild-type allele as determined by crossing to a null allele to create a flox/- genetic configuration. In addition, exposure of the floxed allele to cre recombinase, either via adenovirus exposure of primary cultures or through matings with tissue-specific promoter-driven cre transgenic mouse lines, demonstrated the recombinogenic capacity of the locus (Zhu et al. 2001).

\section{NF1 AND NEUROFIBROMAS}

A predominant feature of NF1 pathology is the appearance of neurofibromas. These tumors are otherwise rare and are always associated with peripheral nerves and contain abnormal Schwann cells, fibroblasts, perineural sheath cells, and mast cells (Zhu and Parada 2001; Zhu et al. 2002). Several studies provided evidence that the target cell of tumor initiation in neurofibromas belongs to the Schwann cell lineage (Rutkowski et al. 2000; Muir et al. 2001; Perry et al. 2001). Using our conditional NF1 knockout mouse strain, we demonstrated that in mice, Schwann cell lineage-specific ablation of NF1 is necessary but not sufficient for generation of tumors resembling plexiform neurofibromas (Zhu et al. 2002). The genetic data demonstrated that tumors only arose when all somatic cells were heterozygous at the NF1 locus $\left(\mathrm{NF}^{+/-}\right)$. In the case in which mice were configured to be nullizygous for NF1 in the Schwann cell lineage but wild type $\left(\mathrm{NF} 1^{\text {flox/flox }}\right)$ throughout all other somatic tissues, they showed evidence of microscopic hyperplasia in sensory ganglia but no tumor development. In the course of these studies, we noted the remarkable infiltration of mast cells into sensory ganglia months prior to tumor formation. Thus, the NF1 $1^{\text {fox } /-}$; Krox20-cre mice (containing $\mathrm{NF}^{-/}$Schwann cells and $\mathrm{NF}^{+/-}$mast cells) had mast cell infiltration and developed tumors, whereas the NF1 $1^{\text {fox/flox; }}$ Krox20-cre mice (containing $\mathrm{NF}^{-/-}$ Schwann cells and $\mathrm{NF}^{+/+}$mast cells) did not exhibit mast cell infiltration into sensory nerves and did not develop tumors. In culture studies, Clapp and colleagues have added considerable strength to this model with their elegant experiments showing that haploinsufficiency at NF1 increased mast cell proliferation, survival, and colony formation in response to Kit Ligand (KitL) (Ingram et al. 2000). Additional recent work from these investigators demonstrated that $\mathrm{NF}^{-/-}$Schwann cells secreted KitL which stimulates mast cell migration, and $\mathrm{NF}^{+/-}$mast cells are hypermotile in response to KitL (Yang et al. 2003). Thus, the current working hypothesis is that $N F 1^{+/-}$mast cells contribute in a fundamental way to the formation of neurofibromas in vivo (Table 1). The interactions between NF1 null Schwann cells and NF1 heterozygous mast cells are very likely to play important roles during tumorigenesis.

To directly test this hypothesis, adoptive transfer of NF1 heterozygous bone marrow into irradiated $N F 1^{\text {fox/flox; }}$ Krox20-cre mice (containing $N F 1^{-/-}$
Table 1. Unique Affinity between Null Schwann Cells and Heterozygous Mast Cells

\begin{tabular}{lcccc}
\hline Genotype & $\begin{array}{c}\text { Schwann } \\
\text { cells }\end{array}$ & $\begin{array}{c}\text { Mast } \\
\text { cells }\end{array}$ & Infiltration & Tumors \\
\hline $\mathrm{NF}^{\text {flox/- }}$ or & $+/-$ & $+/-$ & - & - \\
$\mathrm{NF}^{+/-}$ & & & & \\
$\mathrm{NF}^{\text {flox/flox}} ; \mathrm{K}^{\mathrm{cre+}}$ & $-/-$ & $+/+$ & - & $-/+^{1}$ \\
$\mathrm{NF}^{\text {flox } /-} ; K^{\text {cre+ }}$ & $-/-$ & $+/-$ & +++ & +++ \\
\hline
\end{tabular}

${ }^{1}$ Microscopic Schwann cell hyperplasia.

Schwann cells and $\mathrm{NF}^{+/+}$mast cells) should allow reconstitution of the capacity to form peripheral nerve tumors. Additionally, pharmacological block of mast cell migration or mast cell function should inhibit early mast cell infiltration of peripheral nerves by heterozygous mast cells and thus block subsequent tumor formation. Further study and identification of gene products that participate in this process in both Schwann cells and mast cells will help us further understand the molecular mechanisms mediating tumor formation and possibly develop new therapies to prevent or delay the onset of tumorigenesis in NF1 individuals. Obvious candidates for preclinical trials are drugs that block Kit receptor function, given the hypersensitivity of mast cells to cytokines and the upregulation of KitL in nullizygous Schwann cells.

\section{NF1 AND ASTROCYTOMAS}

Astrocytic tumors or astrocytomas account for a vast majority of primary central nervous system (CNS) tumors (Kleihues and Cavenee 2000; Holland 2001). Grade II-IV astrocytomas are malignant neoplasms that diffusely infiltrate surrounding brain structures. Grade I pilocytic astrocytomas are benign and are generally not infiltrative (Kleihues and Cavenee 2000; Holland 2001; Maher et al. 2001).

As described above, individuals with NF1 germ-line mutations are predisposed to the development of astrocytomas (Listernick and Gutmann 1999; Listernick et al. 1999). NF1-associated pilocytic astrocytomas are benign, but because of frequent localization to the optic nerve, can cause vision impairment and other neurological symptoms.

Functional activation of the ras pathway through upregulation of receptor tyrosine kinases such as PDGF and EGF receptors has been well documented in human astrocytoma (Kleihues and Cavenee 2000; Holland 2001; Maher et al. 2001; Zhu et al. 2002). In fact, because of the absence of effective conventional chemotherapeutic or radiotherapeutic treatments for astrocytoma, surgical intervention has been a common palliative therapy. Surgical specimens have yielded considerable molecular information concerning oncogenes, tumor suppressors, and cell cycle genes that are aberrant in these tumors. Among lowgrade tumors, p53 mutations and amplification of the PDGF receptors is a common feature. Anaplastic (Grade III) tumors exhibit up-regulation of cell cycle genes and loss of the Rb pathway. Finally, Grade IV tumors (GBM) 
exhibit loss of the Pten tumor suppressor and activation of angiogenic factors such as VEGF. Inspection of such data has led to the hypothesis that inactivation of $p 53$ and activation of the ras pathway might be sufficient to engender astrocytoma in mouse models. Efforts to test this hypothesis by using ablation of NF1 as a surrogate of ras activation, together with p53 inactivation, have yielded evidence that this pathway is sufficient to cause tumor formation (Reilly et al. 2000, 2004; Zhu et al. 2005).

Recent developments in the tumor initiation field of research point to the existence of "cancer stem cells" within tumors that likely represent the self-renewing capacity of the tumor (Singh et al. 2004). The characterization of cancer stem cells has drawn many parallels with typical organ stem cells. A critical question now becomes whether the stem cell niche is the source of the tumor initiation cell. The availability of transgenic mouse lines that reproducibly develop glioblastoma within a predictable time frame permits inspection of mice prior to tumor formation (Zhu et al. 2005).

\section{PERSPECTIVES}

The ability to use genetically altered mice to model specific human cancers with molecular fidelity is apparently at hand. Sporadic cancer in humans is a complex process that requires a series of initiating and tumor progression events to occur in successive steps. Our studies using a genetic disease in which the NF1 tumor suppressor is by definition a critical tumor initiation gene greatly simplifies our task. Promising results in the modeling of neurofibromas, MPNSTs, and astrocytomas permit us to probe the tumor genome for critical progression events, be they genetic or epigenetic. In addition, these models that exhibit high penetrance will serve as ideal substrates for experimental therapeutics. It is reasonable to speculate that the lessons learned from studying NF1 mouse tumor models may have general applicability to sporadic cancer. As a negative regulator of the ras pathway, loss of NF1 is equivalent to limited ras activation. Ras activation is a common feature of human cancer. Finally, as attention focuses on the role of the microenvironment and inflammation in cancer, the unique interaction of loss of NF1 in the Schwann cell and the heterozygous mast cell should provide insight into the non-cell-autonomous mechanisms of cancer progression.

\section{ACKNOWLEDGMENTS}

L.F.P. is an American Cancer Society Professor and is funded by the National Institute of Neurological Disorders and Stroke and the Department of Defense. The authors thank the members of the Parada lab for helpful discussions.

\section{REFERENCES}

Ballester R., Marchuk D., Boguski M., Saulino A., Letcher R., Wigler M., and Collins F. 1990. The NF1 locus encodes a protein functionally related to mammalian GAP and yeast IRA proteins. Cell 63: 851 .
Bollag G. and McCormick F. 1991. Differential regulation of rasGAP and neurofibromatosis gene product activities. $\mathrm{Na}$ ture 351: 576.

Brannan C.I., Perkins A.S., Vogel K.S., Ratner N., Nordlund M.L., Reid S.W., Buchberg A.M., Jenkins N.A., Parada L.F., and Copeland N.G. 1994. Targeted disruption of the neurofibromatosis type-1 gene leads to developmental abnormalities in heart and various neural crest-derived tissues (erratum in Genes Dev. [1994] 8: 2792). Genes Dev. 8: 1019.

Cichowski K. and Jacks T. 2001. NF1 tumor suppressor gene function: Narrowing the GAP. Cell 104: 593.

Cichowski K., Shih T.S., Schmitt E., Santiago S., Reilly K., McLaughlin M.E., Bronson R.T., and Jacks T. 1999. Mouse models of tumor development in neurofibromatosis type 1 . Science 286: 2172.

Guo H.F., The I., Hannan F., Bernards A., and Y. Zhong Y. 1997. Requirement of Drosophila NF1 for activation of adenylyl cyclase by PACAP38-like neuropeptides. Science 276: 795 .

Holland E.C. 2001. Gliomagenesis: Genetic alterations and mouse models. Nat. Rev. Genet. 2: 120.

Ingram D.A., Yang F.C., Travers J.B., Wenning M.J., Hiatt K., New S., Hood A., Shannon K., Williams D.A., and Clapp D.W. 2000. Genetic and biochemical evidence that haploinsufficiency of the Nf1 tumor suppressor gene modulates melanocyte and mast cell fates in vivo. J. Exp. Med. 191: 181.

Jacks T., Shih T.S., Schmitt E.M., Bronson R.T., Bernards A., and Weinberg R.A. 1994. Tumour predisposition in mice heterozygous for a targeted mutation in Nf1. Nat. Genet. 7: 353.

Kleihues P. and Cavenee W.K. 2000. Pathology and genetics of tumours of the nervous system. IARC Press, Lyon, France.

Klesse L.J. and Parada L.F. 1998. p21 ras and phosphatidylinositol-3 kinase are required for survival of wild-type and NF1 mutant sensory neurons. J. Neurosci. 18: 10420.

Le D.T., Kong N., Zhu Y., Lauchle J.O., Aiyigari A., Braun B.S., Wang E., Kogan S.C., Le Beau M.M., Parada L., and Shannon K.M. 2004. Somatic inactivation of Nf1 in hematopoietic cells results in a progressive myeloproliferative disorder. Blood 103: 4243.

Listernick R. and Gutmann D.H. 1999. Tumors of the optic pathway. In Neurofibromatosis: Phenotype, natural history, and pathogenesis (ed. J.M. Friedman et al.), pp. 75-89. Johns Hopkins University Press, Baltimore, Maryland.

Listernick R., Charrow J., and Gutmann D.H. 1999. Intracranial gliomas in neurofibromatosis type 1. Am. J. Med. Genet. 89: 38.

Maher E.A., Furnari F.B., Bachoo R.M., Rowitch D.H., Louis D.N., Cavenee W.K., and DePinho R.A. 2001. Malignant glioma: Genetics and biology of a grave matter. Genes Dev. 15: 1311.

Muir D., Neubauer D., Lim I.T., Yachnis A.T., and Wallace M.R. 2001. Tumorigenic properties of neurofibromin-deficient neurofibroma Schwann cells. Am. J. Pathol. 158: 501.

Perry A., Roth K.A., Banerjee R., Fuller C.E., and Gutmann D.H. 2001. NF1 deletions in S-100 protein-positive and negative cells of sporadic and neurofibromatosis 1 (NF1)-associated plexiform neurofibromas and malignant peripheral nerve sheath tumors. Am. J. Pathol. 159: 57.

Reilly K.M., Loisel D.A., Bronson R.T., McLaughlin M.E., and Jacks T. 2000. Nf1;Trp53 mutant mice develop glioblastoma with evidence of strain-specific effects. Nat. Genet. 26: 109.

Reilly K.M., Tuskan R.G., Christy E., Loisel D.A., Ledger J., Bronson R.T., Smith C.D., Tsang S., Munroe D.J., and Jacks T. 2004. Susceptibility to astrocytoma in mice mutant for Nf1 and Trp53 is linked to chromosome 11 and subject to epigenetic effects. Proc. Natl. Acad. Sci. 101: 13008.

Rutkowski J.L., Wu K., Gutmann D.H., Boyer P.J., and Legius E. 2000. Genetic and cellular defects contributing to benign tumor formation in neurofibromatosis type 1. Hum. Mol. Genet. 9: 1059.

Singh S.K., Hawkins C., Clarke I.D., Squire J.A., Bayani J., Hide T., Henkelman R.M., Cusimano M.D., and Dirks P.B. 2004. Identification of human brain tumour initiating cells. Nature 432: 396. 
The I., Hannigan G.E., Cowley G.S., Reginald S., Zhong Y., Gusella J.F., Hariharan I.K., and Bernards A. 1997. Rescue of a Drosophila NF1 mutant phenotype by protein kinase A. Science 276: 791.

Viskochil D.H. 1999. The structure and function of the NF1 gene: Molecular pathology. In Neurofibromatosis: Phenotype, natural history, and pathogenesis (ed. J.M. Friedman et al.), p. 119. Johns Hopkins University Press, Baltimore, Maryland.

Vogel K.S., Klesse L.J., Velasco-Miguel S., Meyers K., Rushing E.J., and Parada L.F. 1999. Mouse tumor model for neurofibromatosis type 1. Science 286: 2176.

Xu G.F., Lin B., Tanaka K., Dunn D., Wood D., Gesteland R., White R., Weiss R., and Tamanoi F. 1990a. The catalytic domain of the neurofibromatosis type 1 gene product stimulates ras GTPase and complements ira mutants of $S$. cerevisiae. Cell 63: 835.

Xu G.F., O'Connell P., Viskochil D., Cawthon R., Robertson M., Culver M., Dunn D., Stevens J., Gesteland R., and White R., et al. 1990b. The neurofibromatosis type 1 gene encodes a protein related to GAP. Cell 62: 599.
Yang F.C., Ingram D.A., Chen S., Hingtgen C.M., Ratner N., Monk K.R., Clegg T., White H., Mead L., Wenning M.J., Williams D.A., Kapur R., Atkinson S.J., and Clapp D.W. 2003. Neurofibromin-deficient Schwann cells secrete a potent migratory stimulus for $\mathrm{Nf1}+/-$ mast cells. J. Clin. Invest. 112: 1851.

Zhu Y. and Parada L.F. 2001. Neurofibromin, a tumor suppressor in the nervous system. Exp. Cell Res. 264: 19.

. 2002. The molecular and genetic basis of neurological tumours. Nat. Rev. Cancer 2: 616.

Zhu Y., Ghosh P., Charnay P., Burns D.K., and Parada L.F. 2002. Neurofibromas in NF1: Schwann cell origin and role of tumor environment. Science 296: 920.

Zhu Y., Guignard F., Zhao D., Liu L., Burns D.K., Mason R.P., Messing A., and Parada L.F. 2005. Early inactivation of p53 tumor suppressor gene cooperating with NF1 loss induces malignant astrocytoma. Cancer Cell 8: 119.

Zhu Y., Romero M.I., Ghosh P., Ye Z., Charnay P., Rushing E.J., Marth J.D., and Parada L.F. 2001. Ablation of NF1 function in neurons induces abnormal development of cerebral cortex and reactive gliosis in the brain. Genes Dev. 15: 859 . 


\section{$8_{8}^{\infty} \mathrm{CSH} \&$ Cold Spring Harbor Symposia SYMPOSIA on Quantitative Biology}

\section{Modeling Neurofibromatosis Type 1 Tumors in the Mouse for Therapeutic Intervention}

L.F. PARADA, C.-H. KWON and Y. ZHU

Cold Spring Harb Symp Quant Biol 2005 70: 173-176

Access the most recent version at doi:10.1101/sqb.2005.70.025

References This article cites 29 articles, 12 of which can be accessed free at: http://symposium.cshlp.org/content/70/173.full.html\#ref-list-1

License

Email Alerting Receive free email alerts when new articles cite this article - sign up in Service the box at the top right corner of the article or click here. 